\title{
Effect of heat treatment on starch granule structure and nutrient content of germinated purple rice
}

\author{
Sakaewan KHANTARATE ${ }^{1}$, Parichat THEANJUMPOL ${ }^{2}$, Nattasak KRITTIGAMAS ${ }^{3}$, Sangtiwa SURIYONG ${ }^{3 *}$
}

\begin{abstract}
This study aims to determine the effect of heat treatments on milling quality and some nutrients of germinated glutinous purple rice; we performed an experiment in a $3 \times 2$ factorial design with three replications. The first factors were three heating methods, namely; baking $\left(80,100^{\circ} \mathrm{C}\right)$ and steaming $\left(100^{\circ} \mathrm{C}\right)$, and the second factors were two heating periods (15 and 30 min). Dried germinated rice was used as control. Heating method and duration as well as their interactions, significantly affected the milling quality and anthocyanin extraction $(\mathrm{P}<0.05)$. Steaming at $100{ }^{\circ} \mathrm{C}$ for $30 \mathrm{~min}$ significantly increased head rice $(73.4 \%)$, while baking at $100^{\circ} \mathrm{C}$ for $30 \mathrm{~min}$ resulted in the highest amount of broken rice $(42.3 \%)$. These method also maintained the GABA ( $\gamma$-aminobutyric acid) content of the rice, while anthocyanin extraction was decreased from 52.1 to $29.9 \mathrm{mg} \cdot \mathrm{g}^{-1}$. Heating at $80{ }^{\circ} \mathrm{C}$ for $30 \mathrm{~min}, 100^{\circ} \mathrm{C}$ for 10 and $20 \mathrm{~min}$ and $125^{\circ} \mathrm{C}$ resulted in a higher free radical scavenging ability when compared to unheated rice.
\end{abstract}

Keywords: germinated rice; heat treatment; milling quality; anthocyanins; GABA.

Practical Application: Stop germinated purple glutinous rice using heat treatments.

\section{Introduction}

In Thailand, purple glutinous rice (Oryza sativa L.) is a local race genotype, grown widely in different geographical areas across the country and varying phenotype pigmentation. Rice with purple pigments in the husk (hull) and pericarp contains a unique characteristic called "anthocyanin". The accumulated substances are effective compounds with medicinal properties, preventing or delaying some types of cell damage because of a range of antioxidants (Hu et al., 2003; Gujral \& Rosell, 2004). Anthocyanins also contain numerous bioactivities, such as reactive oxygen species (ROS) scavenging and potential agents for preventing and treating oxidative stress-related diseases, anti-atherosclerosis, hypoglycaemic properties as well as, anti-allergic activities (Deng et al., 2013; Li et al., 2014). These compounds also reduce the risk of cancer and enhance immunity (Banjerdpongchai et al., 2013).

Rice consumers can obtain the health benefits not only because of the nutrients contained in the whole grains of pigmented rice, but also when consuming germinated rice. Germinated rice, as a functional food, aids in digestion and absorption and contains nutrients such as gamma-amino butyric acid (GABA) and ferulic acid in higher amounts than un-germinated brown rice (Patil \& Khan, 2011). GABA is a four carbon non-protein amino acid, produced primarily by the decarboxylation of L-glutamic acid, catalysed by the enzyme glutamate decarboxylase during the germination of brown rice (Saikusa et al., 1994). In previous studies, soaking 21 rice varieties increased the GABA content from 3.96 to $10.04 \mathrm{mg} / 100 \mathrm{~g}$ dry matter after $12 \mathrm{~h}$, reaching the highest levels of $17.87 \mathrm{mg} / 100 \mathrm{~g}$ dry matter at $24 \mathrm{~h}$, followed by a continuous decrease to 9.91 and $1.36 \mathrm{mg} / 100 \mathrm{~g}$ dry matter at 36 and 48 h, respectively. At 24 h, the white rice variety KDML 105 and the purple rice variety Kum Doi Saket (23.48 and $23.63 \mathrm{mg} / 100 \mathrm{~g}$ dry matter, respectively) exhibited the highest GABA contents of all 21 rice varieties (Karladee \& Suriyong, 2012). Gamma-amino butyric acid is a neurotransmitter in the brain and the spinal cord of mammals, inducing hypotensive, diuretic and tranquillizing effects (Wu et al., 2013). It also is a neurotransmitter inhibitor in the central nervous system and helps to relax the brain, facilitates sleep and prevents fat accumulation in the body (Akama et al., 2009)

The development of value added traditional germinated rice products is one approach to facilitate the uptake of these nutrients by consumers. However, only of fragrant white rice without pigmented colour had been brought through traditionally process. Then the glutinous purple rice is an alternative material which rich of the antioxidative nutrients. When it approved through the germination process, the products could be fulfilled by GABA content. However, heat treatment involved not only deactivating the enzymes concerning with the seed germination but also it maintain beneficial nutrients and stabilization of the grain. In this context, we evaluated the effects of heat treatment on the colour quality and the amount of anthocyanin extract in germinated glutinous rice. 


\section{Materials and methods}

The improved purple glutinous rice variety (Oryza sativa L.) used in this study was released from the Faculty of Agriculture, Chiang Mai University, and grown at the agronomy field plot in the Maehia Station Center. The Kum Doi Saket (KDSK) is popular pigmented glutinous rice in northern Thailand. It is rich in anthocyanin in the pericarp, which is responsible for the purple and black rice colour.

\subsection{Preparation of germinated purple rice}

The glutinous purple rice cv. KDSK was grown under the aquatic field conditions and normal agronomic practices required for photosensitive rice. The rice was cleaned and uniform in size, and a subsample was used for the germination test according to ISTA (International Seed Testing Association, 2003). For each treatment, a 700-gram portion was soaked in $1,000 \mathrm{~mL}$ of deionised water for $8 \mathrm{~h}$ and placed in cloth bag. The samples were then placed in a plastic box and incubated at $30{ }^{\circ} \mathrm{C}$ for $24 \mathrm{~h}$. Subsequently, the germinated rice was subjected to different thermal treatments.

\subsection{Experimental design}

A factorial design with four replicates was applied: heat conditions of six treatments (baking at 80 and $100{ }^{\circ} \mathrm{C}$ and steaming at $100^{\circ} \mathrm{C}$ ) were the main factors, while heat durations ( 15 and $30 \mathrm{~min}$ ) were the sub factors. Germinated rice dried at $35^{\circ} \mathrm{C}$ for $6 \mathrm{~h}$ was used as control. The germinated rice was cooked, followed by the treatments and drying $\left(\right.$ at $\left.35^{\circ} \mathrm{C}\right)$ until it reached a final moisture content of $14.5 \pm 0.02 \%$ (dry base), representing the safe moisture value for grain storage. In the treated samples, we determined milling quality, micro structure and some chemical nutrients as followed.

\subsection{Milling quality}

From each germinated sample, $125 \mathrm{~g}$ were used to determine milling quality, First, we de-hulled and cleaned the sample using a bench-top husker (Sheller model P-1, Ngek Seng Huat Part., Ltd., Bangkok, Thailand), flowed by determining the head rice recovery (yield). We also measured the head rice (\%) and broken rice (\%) on a weight basis.

\subsection{Microbiological observation}

After the heat treatments, the microstructures of germinated rice samples with difference time periods were observed to evaluate the effect of heat on the structural properties of the rice grain, using a scanning electron microscope (SEM) (JSM-5410-LV, JEOL Ltd., Tokyo, Japan). The germinated rice grains used in this experiment were de-hulled and broken off manually along the short axis, and the untouched broken surfaces were used for the observation. On each broken surface, two locations were selected: one was about $0.1-0.2 \mathrm{~mm}$ from the lateral surface and designated as the outer layer endosperm $(1,000 \mathrm{x})$, the other was about $0.8-1.0 \mathrm{~mm}$ from the lateral surface and designated as the inner endosperm $(3,000 \mathrm{x})$.

\subsection{Chemical determination}

\section{Determination of anthocyanin}

The total monomeric anthocyanin pigment content of the rice samples was determined by the $\mathrm{pH}$ differential method described by Giusti \& Wrolstad (2001), with slight modifications. For the obtained solution, we measured absorbance at 521 and $700 \mathrm{~nm}$. Total anthocyanin (TA), as cyanidin-3-glucoside was calculated by the following Equations 1 and 2:

$A=\left(A_{510}-A_{700}\right) p H_{1.0}-\left(A_{510}-A_{700}\right) p H_{4.5}$

Anthocyanin contents $=(A \times M W \times D F \times 1000) /(\varepsilon \times l)$

where $\mathrm{A}$ is the absorbance difference at various $\mathrm{pH}$ values, $\mathrm{MW}$ is the molecular weight $(449.2 \mathrm{~g} / \mathrm{mol})$ of cyanidine-3-glucoside, $\mathrm{DF}$ is the dilution factor, molar apsorptivity $(\varepsilon)$ is $26,900 \mathrm{M} . \mathrm{cm}$ and path length (l) is $1.0 \mathrm{~cm}$.

\section{Determination of $G A B A$}

The GABA content was analyzed according to Kitaoka \& Nakano (1969), with some modifications. Optical density was determined by spectrophotometry at a wavelength of $630 \mathrm{~nm}$, with $2 \mathrm{~mL}$ ethanol as blank. The GABA content was quantified by comparing the optical density reading with the standard GABA content curve.

\section{Antioxidant capacity by DPPH assay}

The DPPH assay was performed according to the method developed by Blois (1958) and modified by Brand-Williams et al. (1995). The assay is based on the measurement of the scavenging capacity of antioxidants towards 2, 2-diphenyl-1-picrylhydrazyl (DPPH) radicals. The decrease in absorbance was measured at $517 \mathrm{~nm}$ after $30 \mathrm{~min}$ of incubation at room temperature, using a UV-VIS spectrophotometer 1700 (SPECORD ${ }^{\circ}$ 40, Analytik Jena AG, Germany). The scavenging activity of the sample extract was expressed as the inhibition of DPPH radical and calculated according to the following Equation 3:

Scavenging activity $(\%)=\left[\left(A_{\text {control }}-A_{\text {sample }}\right) / A_{\text {control }}\right] \times 100$

where $\mathrm{A}_{\text {control }}$ (containing DPPH solution) and $\mathrm{A}_{\text {sample }}$ represent the absorbances with different dilutions of rice extract. Using standard curves for the reaction of Trolox with DPPH, the data were then converted into activity in terms of $\mu$ moles Trolox Equivalents/100 grams sample (TE).

\subsection{Statistical analysis}

All data were subjected to analysis of variance (ANOVA) using a statistical program (Statistix, Analytical Software, USA). Differences were considered significant at $\mathrm{P}<0.05$, and the averages were determined by the least significant difference test. Pearson's correlations were analyzed between various parameters. 


\section{Results and discussion}

The microstructure of germinated purple rice grains subjected different heat treatments is shown in Figures 1 and 2. The changes in size and shape of starch granules suggest influences of the different heat treatments. At the endosperm layer, the starch granules after drying (control) were mostly relatively large (Figure 1a). After baking at $80{ }^{\circ} \mathrm{C}$ for $15-30 \mathrm{~min}$, some small starch granules were observed (Figure $1 \mathrm{~b}$ and $1 \mathrm{c}$ ). With increasing temperatures to $100^{\circ} \mathrm{C}$ for $15-30 \mathrm{~min}$, the amount of small size granules increased (Figure 1d and 1e). These changes were due to the decreased moisture content, and some starch granules were fractured along the cleaved molecules; these fractures were more pronounced at longer incubation times. At the same time, small starch granules appeared. However, when the inner endosperm of steam-germinated rice was heated at $100{ }^{\circ} \mathrm{C}$ for $15-30 \mathrm{~min}$ (Figure $1 \mathrm{f}$ and $1 \mathrm{~g}$ ), it was absorbed into the starch and became an integral part of the biopolymer during gelatinization. This process leads to the loss of crystallinity of the granule, and its internal structure turns amorphous (Parada \& Aguilera, 2012). Similarly, Jung et al. (2017) also suggested that the re-association of starch molecules leading to the retrogradation and expulsion of water aggregates from the starch network contributed to an increased hardness of gelatinized rice grain.

After germination, the hulls were removed to become purple glutinous brown rice. It composed with the mass distribution of caryopsis which is $1-2 \%$ of aleurone plus seed coat, nucellus (4-6\%) and starchy endosperm (89-94\%) (Zhou et al., 2002). In this study, after drying and baking at 80 and $100{ }^{\circ} \mathrm{C}$ for $15 \mathrm{~min}$, the aleurone layer surrounding the endosperm was composed of a single cell layer (Figure 2a-c), with clearly uniform cell shapes throughout (Figure $2 \mathrm{~d}$ ). After baking at $100{ }^{\circ} \mathrm{C}$ for $30 \mathrm{~min}$ and steaming for $15-30 \mathrm{~min}$, the thermal processes resulted in a negligible extent of gelatinization between the bran layer and the outer endosperm (Figure 2e-g). A previous study also reported that after steaming, the starch granules seemed to be partially gelatinized and packed together (Chang \& Yang, 1992).

After germination and heat treatment, the removal of the hull during milling produces purple germinated brown rice, in which the head rice has a size of more than $8 / 10$ that of the average length of whole rice grain, while broken rice grains have a size of less than $8 / 10$. The head rice recovery rates of dried germinated purple rice (control) were 44.7 and $31.5 \%$ of broken rice, without any difference between the rice baked at $80{ }^{\circ} \mathrm{C}$ for 15 and $30 \mathrm{~min}$ (head rice accounting for 46.5 and $44.9 \%$, respectively). However, baking the rice at $100{ }^{\circ} \mathrm{C}$ decreased head rice recovery, especially $30 \mathrm{~min}$ of heating, resulting in the lowest head rice yield of $32.7 \%$ and the highest broken rice yield of $42.3 \%$. On the other hand, germinated rice subjected to steaming at $100{ }^{\circ} \mathrm{C}$ showed a significantly higher head rice yield and a significantly lower broken rice yield, especially at $100{ }^{\circ} \mathrm{C}$ for $30 \mathrm{~min}(73.4 \%$ and $4.4 \%$, respectively; Table 1$)$. Therefore, steaming may be the optimum treatment to maximize head recovery. A similar result has been recorded for drying at different air temperature; water absorption and the ratio of stickiness and hardness decreased with increasing temperature, longer exposure/drying times, longer tempering period between treatments, rapid water removal also resulted in decreased head rice yield (Inprasit \& Noomhorm, 2001).

The total anthocyanin and flavonoid contents in the rice caryopsis varied significantly among the different treatments. Germinated rice subjected to low cooking temperatures showed a total anthocyanin level of $52.1 \mathrm{mg} \cdot \mathrm{g}^{-1}$. After the rice samples were exposed to a temperature of $80^{\circ} \mathrm{C}$ for $15-30 \mathrm{~min}$, the content was significantly increased to $59.2-60.7 \mathrm{mg} \cdot \mathrm{g}^{-1}$, subjecting rice to
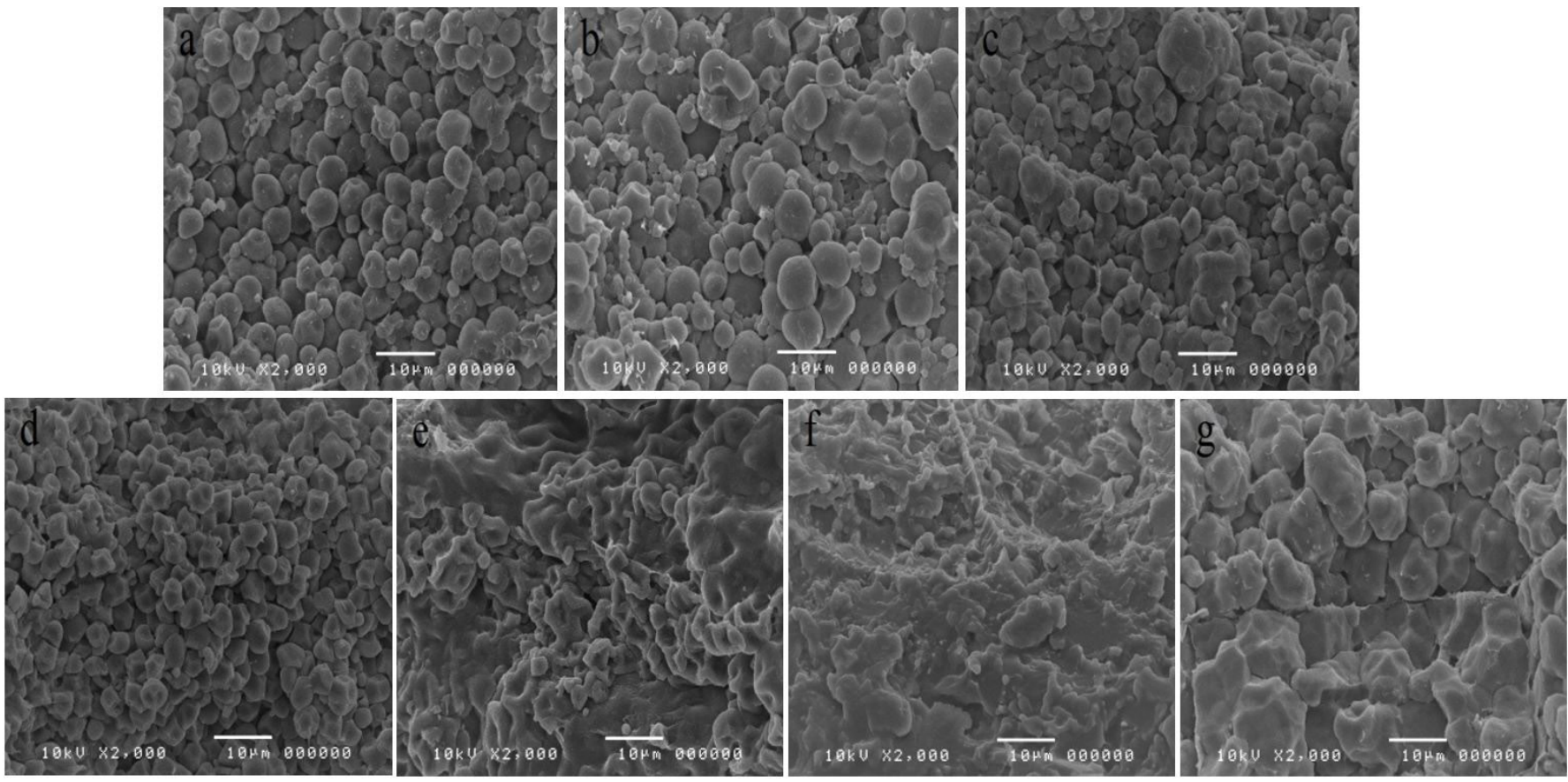

Figure 1. Effects of heating methods on the starch structure of the outer rice endosperm: (a) drying (a); baking $80^{\circ} \mathrm{C}, 15 \mathrm{~min}$ (b), $30 \mathrm{~min}$ (c); $100^{\circ} \mathrm{C}, 15 \min (\mathrm{d}), 30 \mathrm{~min}(\mathrm{e})$; steaming $100^{\circ} \mathrm{C}, 15 \mathrm{~min}(\mathrm{f}), 30 \mathrm{~min}(\mathrm{~g})$. 

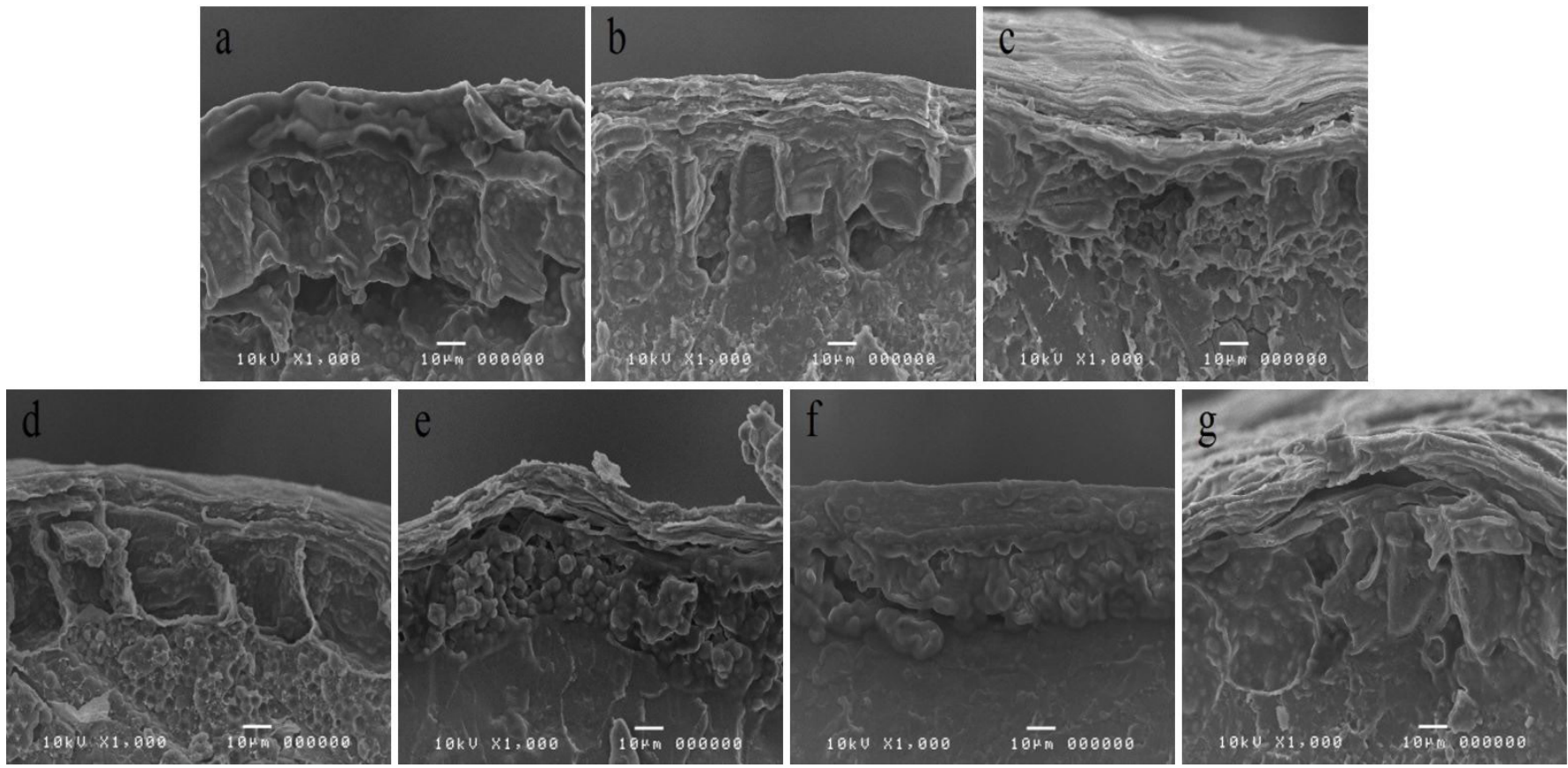

Figure 2. Effects of heating methods on the starch structure of the pericarp of germinated rice grains: drying (a); baking $80{ }^{\circ} \mathrm{C}, 15$ min (b); 30 $\min (\mathrm{c}) ; 100^{\circ} \mathrm{C}, 15 \min (\mathrm{d}) ; 30 \mathrm{~min}(\mathrm{e})$; steaming $100^{\circ} \mathrm{C}, 15 \mathrm{~min}(\mathrm{f}) ; 30 \mathrm{~min}(\mathrm{~g})$.

Table 1. Effects of heat treatments on milling quality of germinated purple rice.

\begin{tabular}{|c|c|c|c|c|}
\hline Heating method & Temperature $\left({ }^{\circ} \mathrm{C}\right)$ & Duration (min) & Head rice (\%) & Broken rice (\%) \\
\hline Drying & & & $44.7 \pm 2.2^{\text {cd }}$ & $31.6 \pm 2.2^{\mathrm{bc}}$ \\
\hline \multirow[t]{2}{*}{ Baking } & 80 & 15 & $46.5 \pm 1.8^{c}$ & $29.3 \pm 1.4^{c}$ \\
\hline & 80 & 30 & $44.9 \pm 1.3^{c}$ & $31.2 \pm 1.1^{\mathrm{bc}}$ \\
\hline \multirow[t]{2}{*}{ Baking } & 100 & 15 & $41.6 \pm 3.7^{\mathrm{d}}$ & $33.4 \pm 3.7^{\mathrm{b}}$ \\
\hline & 100 & 30 & $32.7 \pm 2.3^{e}$ & $42.3 \pm 1.6^{\mathrm{a}}$ \\
\hline \multirow[t]{2}{*}{ Steaming } & 100 & 15 & $67.8 \pm 3.1^{\mathrm{b}}$ & $9.2 \pm 3.7^{\mathrm{d}}$ \\
\hline & 100 & 30 & $73.4 \pm 1.9^{\mathrm{a}}$ & $4.4 \pm 1.8^{\mathrm{e}}$ \\
\hline $\operatorname{LSD}_{0.05}$ Method (M) & & & * & * \\
\hline $\mathrm{LSD}_{0.05}$ Method time $(\mathrm{T})$ & & & ns & ns \\
\hline $\mathrm{LSD}_{0.05} \mathrm{M} \times \mathrm{T}$ & & & * & * \\
\hline
\end{tabular}

Sample means with different lowercase letters in the same column differ significantly at the least significant difference (LSD.) test with a confidence interval of $95 \% .{ }^{*}$ The factor was significantly different; ns means no significant difference by analysis of variance (ANOVA) at the confidence interval of $95 \%$.

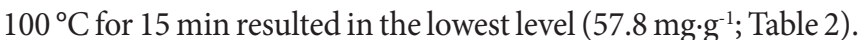
These results are in agreement with the findings of Hou et al. (2013), who reported that the degradation rate of monomeric anthocyanin increased with increasing heating temperatures. In another study, anthocyanins were reasonably stable during heating of black carrots at $70-80{ }^{\circ} \mathrm{C}$ (Cemeroglu et al., 1994), which is in accordance with the kinetic data on the thermal stability of black carrot anthocyanins between 70 and $90{ }^{\circ} \mathrm{C}$ (Rhim, 2002). In a study investigating the thermal stability of bilberry extract, anthocyanin could be either broken down to small molecules or lost its conjugated sugar during heat treatment (Yue \& Xu, 2008). However, the production of anthocynins was suppressed after $30 \mathrm{~min}$ at $100^{\circ} \mathrm{C}$. These finding are similar to those of Loypimai et al. (2016), who report that the level of anthocyanin in rice bran increased with increasing temperatures from 60 to $100{ }^{\circ} \mathrm{C}$. In contrast, when steaming at the same temperature, degradation was less stable. The total anthocyanin content in germinated rice was reduced to 31 and $46 \%$ after steaming at $100{ }^{\circ} \mathrm{C}$ for 15 and $30 \mathrm{~min}$, respectively. Stapley et al. (1999) stated that when steam is taken up by the grain, it is ultimately absorbed as liquid water. Since this involves a phase change, the accompanying liberation of latent heat will raise the grain temperature. Thermocouple measurements confirm that the grain temperature is slightly higher than the surrounding steam temperature. The distribution of water in the grains can be attributed to starch gelatinization, especially in purple glutinous rice, which contains high amylopectin levels. Several studies suggest that amylopectin has a high swelling power and is disrupted more easily during heating (Wadchararat et al., 2006; Techawipharat et al., 2008; Bosmans et al., 2013). Therefore, the higher the amylopectin content, the less compact the starch granule and the starch can more easily flow outside the granules. Because anthocyanin is mainly accumulated in the 
Table 2. Effects of heat treatments on some nutrients of germinated purple rice.

\begin{tabular}{|c|c|c|c|}
\hline Heating method and duration & Anthocyanin content $\left(\mathrm{mg} \cdot \mathrm{g}^{-1}\right)$ & GABA content $\left(\mathrm{mg} \cdot \mathrm{g}^{-1}\right)$ & DPPH assay (TE/100 g-sample) \\
\hline Drying & $52.1 \pm 2.8^{\mathrm{b}}$ & $40.6 \pm 3.0^{c}$ & $461 \pm 19$ \\
\hline \multicolumn{4}{|l|}{ Baking at $80^{\circ} \mathrm{C}$} \\
\hline $15 \mathrm{~min}$ & $59.2 \pm 2.1^{\mathrm{a}}$ & $25.3 \pm 3.1^{\mathrm{d}}$ & $477 \pm 13$ \\
\hline $30 \mathrm{~min}$ & $60.7 \pm 1.8^{\mathrm{a}}$ & $21.5 \pm 1.7^{\mathrm{de}}$ & $475 \pm 21$ \\
\hline \multicolumn{4}{|l|}{ Baking at $100^{\circ} \mathrm{C}$} \\
\hline $15 \mathrm{~min}$ & $57.8 \pm 2.4^{\mathrm{a}}$ & $25.0 \pm 3.1^{\mathrm{d}}$ & $450 \pm 28$ \\
\hline $30 \mathrm{~min}$ & $53.5 \pm 2.5^{\mathrm{b}}$ & $20.8 \pm 0.8^{e}$ & $446 \pm 23$ \\
\hline \multicolumn{4}{|l|}{ Steaming at $100^{\circ} \mathrm{C}$} \\
\hline $15 \mathrm{~min}$ & $35.9 \pm 1.3^{c}$ & $48.9 \pm 2.8^{\mathrm{b}}$ & $100 \pm 15$ \\
\hline $30 \mathrm{~min}$ & $27.1 \pm 1.2^{\mathrm{d}}$ & $54.9 \pm 3.9^{\mathrm{a}}$ & $99 \pm 12$ \\
\hline $\operatorname{LSD}_{0.05}$ Method (M) & * & * & * \\
\hline $\mathrm{LSD}_{0.05}$ Method time $(\mathrm{T})$ & * & ns & ns \\
\hline $\mathrm{LSD}_{0.05} \mathrm{M} \times \mathrm{T}$ & * & * & ns \\
\hline
\end{tabular}

Sample means with different lowercase letters in the same column differ significantly at the least significant difference (LSD.) test with a confidence interval of $95 \%$. ${ }^{\star}$ The factor was significantly different; ns means no significant difference by analysis of variance (ANOVA) at the confidence interval of $95 \%$.

bran and is a water-soluble pigment, it is lost during steaming when compared to drying.

Tocopherols, tocotrienols and $\gamma$-oryzanol are important compounds with antioxidant activity (Iqbal et al., 2005; Walter \& Marchesan, 2011). In this study, the antioxidant capacity of germinated purple glutinous rice containing anthocyanin after treating with different thermal processes was evaluated via DPPH methods. The results showed that the antioxidant activity of the rice significantly differed among the heat treatments; Table 2. The antioxidant content of dried germinated rice was $461 \mathrm{TE}$, which not differ from rice baked at $80{ }^{\circ} \mathrm{C}$, compared to rice baked at $100^{\circ} \mathrm{C}$, with 450 and 446 TE. Similarly, Yue \& Xu (2008) have investigated the antioxidant activity of bilberry extract and noted that the DPPH free radical scavenging capability of bilberry extract increased initially, followed by a decrease at 100 and $125^{\circ} \mathrm{C}$. Most likely, this is because the degradation products, including phenolic acids and anthocyanins, are not stable at high temperatures.

In parallel with the highest decrease, the percentage of the antioxidant activity as $78.4 \%$ when, steaming for $15-30 \mathrm{~min}$, most likely because of starch gelatinization and leaching out from the hull during steaming. We observed a positive correlation between antioxidant activity and anthocyanin content $(r=0.9275, p=0.000)$, similar to a previous study in which the pigment was significantly correlated to the total antioxidant activity of black rice bran (Koutroubas et al., 2004; Zhang et al., 2010; Rao et al., 2010)

The germination rate in our study was $94 \%$, confirming that the rice grains were available. When grains are soaked, imbibitions starts, and substrate and energy starvation will activate the embryo to produce phytohormones, initiating a signaling cascade that leads to the synthesis of enzymes which, drive the degradation of storage compounds including starch, lipids and proteins for germination (He \& Yang, 2013). In this study, after soaking for $8 \mathrm{~h}$ and incubating for $24 \mathrm{~h}$, amino acids such as GABA were synthesized, with an accelerated production in dried germinated purple glutinous rice $\left(40.6 \mathrm{mg}^{-\mathrm{g}^{-1}}\right)$. The different treatments and time periods affected the GABA content; Table 2. Steaming at $100{ }^{\circ} \mathrm{C}$ for 30 min resulted in the highest content of GABA, which was in accordance with the highest head rice percentage; in previous study, a similar result was observed (Jannoey et al., 2010; Maisont \& Narkrugsa, 2010). On the contrary, the GABA level of germinated rice decreased after baking at 80 and $100{ }^{\circ} \mathrm{C}$ and with longer baking periods. Most likely, the drying method can affect the head rice yield; Table 1, resulting in a higher amount of broken rice and grains without the germ.

\section{Conclusions}

The interaction between processing methods and time period affected the milling quality, the anthocyanin and GABA contents of rice. Anthocyanin is stable up to a temperature $80^{\circ} \mathrm{C}$ and degrades at higher temperatures. Based on SEM analysis of endosperm and pericarp, the starch granules showed different shapes and sizes after heating. Steaming led to gelatinized purple rice grains, with increased hardness and head rice recovery after milling. Since water molecules were expelled from the starch networks, the starch granules eventually burst, resulting in a rapid loss of anthocynin and, consequently, a decreased antioxidant capacity of germinated rice, while the GABA content remained stable or even slightly increased when compared to drying grain. However, total anthocyanin content of germinated rice remained stable at high temperatures, while the GABA content decreased.

\section{Acknowledgements}

This work was supported the Postharvest Technology Innovation Center and the Postharvest Technology Research Center, Faculty of Agriculture, Chiang Mai University, Thailand.

\section{References}

Akama, K., Kanetou, J., Shimosaki, S., Kawakami, K., Tsuchikura, S., \& Takaiwa, F. (2009). Seed specific expression of truncated OsGAD2 produces GABA-enriched rice grains that influence a decrease in blood pressure in spontaneously hypertensive rats. Transgenic 
Research, 18(6), 865-876. http://dx.doi.org/10.1007/s11248-0099272-1. PMid:19434509.

Banjerdpongchai, R., Wudtiwai, B., \& Sringarm, K. (2013). Cytotoxic and apoptotic-inducing effects of purple rice extracts and chemotherapeutic drugs on human cancer cell lines. Asian Pacific Journal of Cancer Prevention, 14(11), 6541-6548. http://dx.doi. org/10.7314/APJCP.2013.14.11.6541. PMid:24377565.

Blois, M. S. (1958). Antioxidant determinations by the use of a stable free radical. Nature, 181(4617), 1199-1200. http://dx.doi. org/10.1038/1811199a0.

Bosmans, G. M., Lagrain, B., Ooms, N., Fierens, E., \& Delcour, J. (2013). A. Biopolymer interactions, water dynamics, and bread crumb firming. Journal of Agricultural and Food Chemistry, 61(19), 4646-4654. http://dx.doi.org/10.1021/jf4010466. PMid:23631677.

Brand-Williams, W., Cuvelier, M. E., \& Berset, C. (1995). Use of a free radical method to evaluate antioxidant activity. Journal of Food Science and Technology, 28, 25-30.

Cemeroglu, B., Velioglu, S., \& Isik, S. (1994). Degradation kinetics of anthocyanins in sour cherry juice and concentration. Journal of Food Science, 59(6), 1216-1218. http://dx.doi.org/10.1111/j.1365-2621.1994. tb14680.x.

Chang, S. M., \& Yang, H. C. (1992). Thermal processing effects on rice characteristics. Food Structure, 11(4), 373-382.

Deng, G. F., Xu, X. R., Zhang, Y., Li, D., Gan, R. Y., \& Li, H. B. (2013). Phenolic compounds and bioactivities of pigmented rice. Critical Reviews in Food Science and Nutrition, 53(3), 296-306. http://dx.doi. org/10.1080/10408398.2010.529624. PMid:23216001.

Giusti, M. M., \& Wrolstad, R. E. (2001). Characterization and measurement of anthocyanins by UV-visible spectroscopy. In R. E. Wrolstad (Ed.), Current protocols in food analytical chemistry (pp. F1.2.1-F1.2.13). New York: John Wiley \& Sons.

Gujral, H. S., \& Rosell, C. M. (2004). Functionality of rice flour modified with a microbial transglutaminase. Journal of Cereal Science, 39(2), 225-230. http://dx.doi.org/10.1016/j.jcs.2003.10.004.

He, D., \& Yang, P. (2013). Proteomics of rice seed germination. Frontiers of Plant Science, 4, 246. PMid:23847647.

Hou, Z., Qin, P., Zhang, Y., Cui, S., \& Ren, G. (2013). Identification of anthocyanins isolated from black rice (Oryza sativa L.) and their degradation kinetics. Food Research International, 50(2), 691-697. http://dx.doi.org/10.1016/j.foodres.2011.07.037.

Hu, C., Zawistowski, J., Ling, W., \& Kitts, D. D. (2003). Black rice (Oryza sativa L. indica) pigmented fraction suppresses both reactive oxygen species and nitric oxide in chemical and biological model systems. Journal of Agricultural and Food Chemistry, 51(18), 5271-5277. http://dx.doi.org/10.1021/jf034466n. PMid:12926869.

Inprasit, C., \& Noomhorm, A. (2001). Effect of drying air temperature and grain temperature of different types of dryer and operation on rice quality. Drying Technology, 19(2), 389-404. http://dx.doi. org/10.1081/DRT-100102912.

Iqbal, S., Bhanger, M. I., \& Anwar, F. (2005). Antioxidant properties and components of some commercially available varieties of rice bran in Pakistan. Food Chemistry, 93(2), 265-272. http://dx.doi. org/10.1016/j.foodchem.2004.09.024.

International Seed Testing Association. (2003). International Rules for Seed Testing 2003. Bassersdorf, Switzerland: ISTA.

Jannoey, P., Niamsup, H., Lumyong, S., Tajima, S., Nomura, M., \& Chairote, G. (2010). $\gamma$-Aminobutyric acid (GABA) accumulations in rice during germination. Warasan Khana Witthayasat Maha Witthayalai Chiang Mai, 37(1), 124-133.
Jung, K. J., Lee, H., Lee, S. H., \& Kim, J. K. (2017). Retrogradation of heat-gelatinized rice grain in sealed packaging: investigation of moisture relocation. Food Science and Technology (Campinas), 37(1), 97-102. http://dx.doi.org/10.1590/1678-457x.07816.

Karladee, D., \& Suriyong, S. (2012). $\gamma$-Aminobutyric acid (GABA) content in different varieties of brown rice during germination. Science Asia, 38(1), 13-17. http://dx.doi.org/10.2306/scienceasia1513-1874.2012.38.013.

Kitaoka, S., \& Nakano, Y. (1969). Colorimetric determination of $\gamma$-amino acid. Journal of Biochemistry, 66(1), 87-94. http://dx.doi.org/10.1093/ oxfordjournals.jbchem.a129124. PMid:5821840.

Koutroubas, S. D., Mazzini, F., Pons, B., \& Ntanos, D. A. (2004). Grain quality variation and relationships with morphophysiological traits in rice (Oryza sativa L.) genetic resources in Europe. Field Crops Research, 86(2-3), 115-130. http://dx.doi.org/10.1016/S03784290(03)00117-5.

Li, A. N., Li, S., Zhang, Y. J., Xu, X. R., Chen, Y. M., \& Li, H. B. (2014). Resources and biological activities of natural polyphenols. Nutrients, 6(12), 6020-6047. http://dx.doi.org/10.3390/nu6126020. PMid:25533011.

Loypimai, P., Moongngarm, A., \& Chottanom, P. (2016). Thermal and $\mathrm{pH}$ degradation kinetics of anthocyanins in natural food colorant prepared from black rice bran. Journal of Food Science and Technology, 53(1), 461-470. http://dx.doi.org/10.1007/s13197-0152002-1. PMid:26787965.

Maisont, S., \& Narkrugsa, W. (2010). The Effect of germination on GABA content, chemical composition, total phenolics content and antioxidant capacity of Thai waxy paddy. Witthayasan Kasetsat Witthayasat, 44, 912-923.

Parada, J., \& Aguilera, J. M. (2012). Effect of native crystalline structure of isolated potato starch on gelatinization behavior and consequently on glycemic response. Food Research International, 45(1), 238-243. http://dx.doi.org/10.1016/j.foodres.2011.10.042.

Patil, B. S., \& Khan, K. (2011). Germinated brown rice as a value added rice product: a review. Journal of Food Science and Technology, 48(6), 661-667. http://dx.doi.org/10.1007/s13197-011-0232-4. PMid:23572802.

Rao, A. S., Reddy, S. G., Babu, P. P., \& Reddy, A. R. (2010). The antioxidant and antiproliferative activities of methanolic extracts from Njavara rice bran. BMC Complementary and Alternative Medicine, 10, 4. http://dx.doi.org/10.1186/1472-6882-10-4. PMid:20109194.

Rhim, J. W. (2002). Kinetics of thermal degradation of anthocyanin pigment solutions driven from red flower cabbage. Food Science and Biotechnology, 11, 361-364.

Saikusa, T., Horino, T., \& Mori, Y. (1994). Accumulation of $\gamma$-aminobutyric acid (Gaba) in the rice. Bioscience, Biotechnology, and Biochemistry, 58(12), 2291-2292. http://dx.doi.org/10.1271/bbb.58.2291.

Stapley, A. G. F., Landman, K. A., Please, C. P., \& Fryer, P. J. (1999). Modeling the steaming of whole wheat grains. Chemical Engineering Science, 54(8), 965-975. http://dx.doi.org/10.1016/S0009-2509(98)00404-7.

Techawipharat, J., Suphantharika, M., \& BeMiller, J. N. (2008). Effects of cellulose derivatives and carrageenans on the pasting, paste, and gel properties of rice starches. Carbohydrate Polymers, 73(3), 417426. http://dx.doi.org/10.1016/j.carbpol.2007.12.019.

Wadchararat, C., Thongngam, M., \& Naivikul, O. (2006). Characterization of pregelatinized and heat moisture treated rice flours. Witthayasan Kasetsat Witthayasat, 40(Suppl.), 144-153.

Walter, M., \& Marchesan, E. (2011). Phenolic compounds and antioxidant activity of rice. Brazilian Archives of Biology and Technology, 54(1), 371-377. http://dx.doi.org/10.1590/S1516-89132011000200020. 
Wu, F., Yang, N., Touré, A., Jin, Z., \& Xu, X. (2013). Germinated brown rice and its role in human health. Critical Reviews in Food Science and Nutrition, 53(5), 451-463. http://dx.doi.org/10.1080/1040839 8.2010.542259. PMid:23391013.

Yue, X., \& Xu, Z. (2008). Changes of anthocyanins, anthocyanidins, and antioxidant activity in bilberry extract during dry heating. Journal of Food Science, 73(6), C494-C499. http://dx.doi.org/10.1111/j.17503841.2008.00845.x. PMid:19241540.
Zhang, M. W., Zhang, R. F., Zhang, F. X., \& Liu, R. H. (2010). Phenolic profiles and antioxidant activity of black rice bran of different commercially available varieties. Journal of Agricultural and Food Chemistry, 58(13), 7580-7587. http://dx.doi.org/10.1021/jf1007665. PMid:20521821.

Zhou, Z., Robards, K., Helliwell, S., \& Blanchard, C. (2002). Composition and functional properties of rice. International Journal of Food Science \& Technology, 37(8), 849-868. http://dx.doi.org/10.1046/j.13652621.2002.00625.x 